\title{
First record of Gibberella zeae and Gibberella coronicola on millet in Western Australia
}

\author{
D. G. Wright $\cdot$ R. Khangura $\cdot$ R. Loughman • \\ A. Bentley • J. Fosu-Nyako
}

Received: 5 July 2011 / Accepted: 23 November 2011 / Published online: 14 December 2011

(C) Australasian Plant Pathology Society Inc. 2011

\begin{abstract}
Perithecia carrying asci with mature ascospores were observed on millet stubble (Panicum miliaceum and Panicum sp.) and were identified as Gibberella zeae and Gibberella coronicola for the first time in Western Australia. Morphological identification and molecular assays confirmed the presence of the anamorph Fusarium graminearum and Fusarium pseudograminearum respectively.
\end{abstract}

Keywords Gibberella zeae Gibberella coronicola . Panicum miliaceum · Fusarium head blight . Crown rot

Fusarium graminearum (Schwabe). and F. pseudograminearum (Aoki \& O'Donnell), the causal agent of Fusarium head blight (FHB) and crown rot (CR) of cereals respectively, have been reported in Queensland, northern New South Wales, including the Liverpool Plains area, on wheat, barley, maize and sorghum (Manning et al. 2000). F. pseudograminearum has also been reported in Victoria and South Australia on wheat, and barley (Akinsanmi et al. 2004; Burgess et al. 1975, 2001; Purss 1969, 1971). F. graminearum was first detected in Western Australia (WA) in 1959 on sorghum

D. G. Wright $(\bowtie) \cdot R$. Khangura $\cdot$ R. Loughman

Department of Agriculture and Food, Western Australia, Locked Bag 4, Bentley Delivery Centre,

Perth, WA 6983, Australia

e-mail: dominie.wright@agric.wa.gov.au

\section{A. Bentley}

University of Sydney,

Sydney, NSW, Australia

J. Fosu-Nyako

WA State Agricultural Biotechnology Centre,

School of Biological Sciences and Biotechnology,

Murdoch University,

Perth, WA 6150, Australia causing a stalk rot (Shivas 1989); and more recently in 2004 on wheat and barley grain (Wright et al. 2010).

Gibberalla zeae (Schw.), the teleomorph of F. graminearum is known to occur abundantly in nature throughout the world (Summerell et al. 2001), causing stalk and cob rot of maize and FHB of cereals. The fungus is homothallic and readily produces fertile perithecia in culture. In contrast, $G$. coronicola (Aoki and O'Donnell 1999), the teleomorph of F. pseudograminearum, is less common (Summerell et al. 2001) and generally does not produce perithecia in culture. G. coronicola has been found on mature wheat crops when the soil is wet or after a rain period. In 1996 and 1999, Summerell et al. (2001) collected G. coronicola perithecia associated with high levels of crown rot in wheat crops from the Moree district of NSW. However, in WA neither of the teleomorph stages had been previously detected on cereal grain crops; although, G. zeae had previously been reported as causing foot and root rot in rice (Oryza sativa L.), in Kununurra, WA (Shivas 1989).

With the identification of $F$. graminearum on wheat seeds for the first time in WA in June 2004 (Wright et al. 2010), a field survey was conducted to investigate if the anamorph and teleomorph stages survive in paddocks growing summer small grain cereal crops. The survey was conducted by Department of Agriculture and Food, Western Australia (DAFWA) plant pathologists and local District Office staff. Stubble samples were collected in July and August from locations with a history of summer production of millet for grain or forage production; 33 millet paddocks were inspected and samples collected from Mt Barker to Condingup (Fig. 1).

The stubble collected was examined visually for the presence or absence of perithecia. The size of the perithecia and associated ascospores were measured. Single ascospore cultures were then grown on carnation leaf agar (CLA) and on potato dextrose agar (PDA) for 4 weeks as per protocol 


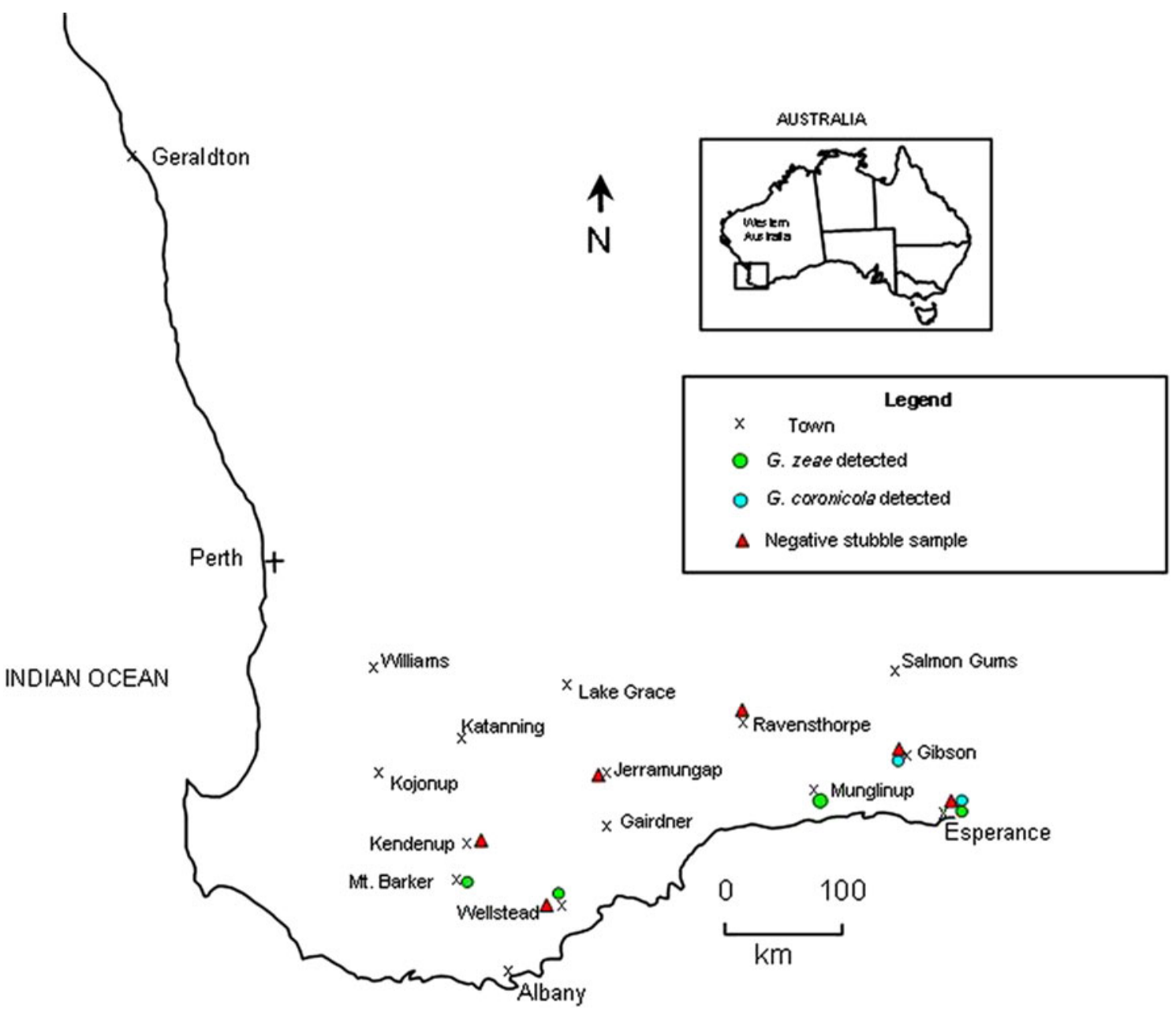

Fig. 1 Map of survey area showing detection of G. zeae and G. coronicola on millet stubble in Western Australia

in Burgess et al. (1994). The anamorph stage of the fungus was then identified morphologically, according to Burgess et al. (1994) and assayed by polymerase chain reaction
(PCR) using species-specific primers to verify results. The primer sets used were: (a) Fg $16 \mathrm{NF}$ and Fg $16 \mathrm{NR}$ for $F$. graminearum (Nicholson et al. 1998); and (b) FPG-F, FPG-

Table 1 Morphological characteristics of perithecia, asci and ascospores of Gibberella zeae and G. coronicola collected from millet stubble (Panicum sp., and P.miliaceum) occurring naturally in the field

\begin{tabular}{|c|c|c|c|c|c|c|c|c|c|}
\hline $\begin{array}{l}\text { WA Culture } \\
\text { Collection } \\
\text { Number (WAC) }\end{array}$ & Location & Host & $\begin{array}{l}\text { Size of } \\
\text { perithecia } \\
\text { (Average } \\
\text { of } 10) \mu \mathrm{m}\end{array}$ & $\begin{array}{l}\text { Colour and } \\
\text { Shape of } \\
\text { perithecia }\end{array}$ & $\begin{array}{l}\text { Size of Asci } \\
(\text { Average } \\
\text { of }>5) \mu \mathrm{m}\end{array}$ & $\begin{array}{l}\text { Size of } \\
\text { Ascospores } \\
\text { (Average of 10) } \\
\mu \mathrm{m}\end{array}$ & $\begin{array}{l}\text { Teleomorph } \\
\text { stage detected }\end{array}$ & $\begin{array}{l}\text { Morphological } \\
\text { results of anamorph } \\
\text { stage }\end{array}$ & PCR results \\
\hline 11426 & Gibson & Panicum sp. & 262.5 & Globose, dark & $82 \times 10$ & $30.7 \times 5.1$ & G. coronicola & F. pseudograminearum & F. pseudograminearum \\
\hline 11428 & Gibson & Panicum sp. & 205.0 & Globose, dark & $88 \times 12$ & $26.9 \times 5$ & G. coronicola & F. pseudograminearum & F. pseudograminearum \\
\hline 11431 & Esperance & Panicum sp. & 316.2 & $\begin{array}{c}\text { Black/Purple } \\
\text { Tuberculate }\end{array}$ & $77 \times 13$ & $30.5 \times 4.5$ & G. coronicola & F. pseudograminearum & F. pseudograminearum \\
\hline 11431 & Esperance & Panicum sp. & 316.2 & $\begin{array}{c}\text { Black/Purple } \\
\text { Tuberculate }\end{array}$ & $77 \times 13$ & $34.5 \times 6.1$ & G. zeae & F. pseudograminearum & F. graminearum \\
\hline 11432 & Mt Barker & $\begin{array}{l}\text { Panicum } \\
\quad \text { miliaceum }\end{array}$ & 286.9 & $\begin{array}{l}\text { Black/Purple } \\
\text { Tuberculate }\end{array}$ & $62.5 \times 10$ & $23.5 \times 5.5$ & G. zeae & F. graminearum & F. graminearum \\
\hline 12340 & Wellstead & Panicum sp. & 212.0 & $\begin{array}{c}\text { Black/Purple } \\
\text { Globose }\end{array}$ & $93.5 \times 10$ & $22.5 \times 5$ & G. zeae & F. graminearum & F. graminearum \\
\hline 12341 & Munglinup & $\begin{array}{l}\text { Panicum } \\
\text { miliaceum }\end{array}$ & 207.1 & $\begin{array}{l}\text { Black/Purple } \\
\text { Tuberculate }\end{array}$ & $76.6 \times 9.6$ & $25 \times 5$ & G. zeae & F. graminearum & F. graminearum \\
\hline
\end{tabular}

WA Western Australia, WAC Western Australia Culture Collection Number 
R (Williams et al. 2002) and Fp 1-1 and Fp 1-2 (Aoki and O’Donnell 1999) for $F$. pseudograminearum.

Based on the morphological characteristics of perithecia, asci and ascospores both G. zeae and G. coronicola were detected on 4 and 2 properties (Table 1) growing millet as a summer grain or forage crop in rotation with winter cereals respectively. The observed perithecia for G. zeae were black/ purple in colour and globose/tuberculate in shape (Table 1). The average diameter of the perithecia was $212 \mu \mathrm{m}$. The ascospores were ellipsoidal, with an average of 3 septa and with no constriction. The size of the ascospores ranged from 22.5-34.5 $\times 5-6.1 \mu \mathrm{m}$, (averaging $26 \times 5.4 \mu \mathrm{m}$ ) consistent with those observed by Summerell et al. (2001). For G. coronicola the observed perithecia were globose and dark and the ascospores were ellipsoidal, generally with 3 septa and a slight constriction at the septa. The size of the ascospores ranged from $22-30 \times 4.4-5 \mu \mathrm{m}$, (averaging $26.5 \times 4.6 \mu \mathrm{m}$ ) (Table 1) and were found to be consistent with the previously published description of this fungus (Summerell et al. 2001).

All single ascospore cultures of G. coronicola were identified as F. pseudograminearum by both morphological and PCR analysis. The PCR analysis on single ascospore cultures of $G$. zeae were confirmed as F. graminearum. Three out of four cultures were also confirmed morphologically to be $F$. graminearum. Because one of the cultures failed to produce perithecia it was identified as F. pseudograminearum. Samples of both the stubble and cultures have been submitted to the WA Culture Collection (WAC) (Table 1).

To our knowledge this is the first report of G. zeae and $G$. coronicola occurring on millet stubble in Western Australia. These findings have implications in the long distance spread of the pathogens G. zeae and G. coronicola associated with the disease Fusarium head blight and Fusarium crown rot in the wheatbelt, where millet is used as a summer rotation crop.

Acknowledgements We would like to thank all Regional and Metro based staff of DAFWA involved in the collection of samples during the survey. We would also like to thank all technical staff involved in the processing of samples and the laborious work involved in the identification of the cultures.

\section{References}

Akinsanmi OA, Mitter V, Simpfendorfer S, Backhouse D, Chakraborty S (2004) Identity and pathogenicity of Fusarium spp. isolated from wheat fields in Queensland and northern New South Wales. Aust J Agric Res 55:97-107

Aoki T, O’Donnell K (1999) Morphological and molecular characterisation of Fusarium pseudograminearum sp. nov., formerly recognised as the Group 1 population of $F$. graminearum. Mycologia 91:597-609

Burgess LW, Backhouse D, Summerell BA, Swan J (2001) Crown rot of wheat. In: Summerell BA, Leslie JF, Backhouse D, Bryden WL, Burgess LW (eds) Fusarium: Paul E. Neslon memorial symposium. APS Press, St Paul, pp 271-294

Burgess LW, Summerell BA, Bullock S, Gott KP, Backhouse D (1994) Laboratory manual for Fusarium research. Fusarium Research Laboratory, The University of Sydney and The Royal Botanical Gardens, Sydney

Burgess LW, Wearing AH, Toussoun TA (1975) Surveys of Fusaria associated with crown rot of wheat in Eastern Australia. Aust J Agric Res 26:791-9

Manning B, Southwell R, Hayman P, Moore K (2000) 'Fusarium head blight in northern NSW'. NSW Agriculture Research Update, AgDex 110/637

Nicholson P, Simpson DR, Weston G, Rezanoor HN, Lees AK, Parry DW, Joyce D (1998) Detection and quantification of Fusarium culmorum and Fusarium graminearum in cereals using PCR assays. Physiol Mol Plant Pathol 53:17-37

Purss GS (1969) The relationship between strains of Fusarium graminearum Schwabe causing crown rot of various gramineous hosts and stalk rot of maize in Queensland. Aust J Agric Res 20:257-264

Purss GS (1971) Pathogenic specialization in Fusarium graminearum. Aust J Agric Res 22:553-561

Shivas R (1989) Fungal and bacterial diseases of plants in Western Australia. J R Soc West Aust 72:1-62

Summerell BA, Burgess LW, Backhouse D, Bullock S, Swan LJ (2001) Natural occurrence of perithecia of Gibberella coronicola on wheat plants with crown rot in Australia. Australas Plant Pathol 30:353-356

Williams KJ, Dennis JI, Smyl C, Wallwork H (2002) The application of species-specific assays based on the polymerase chain reaction to analyse Fusarium crown rot of durum wheat. Australas Plant Pathol 31:119-127

Wright DG, Thomas GJ, Loughman R, Fuso-Nyarko J, Bullock S (2010) Detection of Fusarium graminearum in wheat grains in Western Australia. Australas Plant Dis Notes 5:82-84. doi:10.1071/DN10029 